\title{
Responsible Research and Innovation for the Media Facebook: Community Involvement in the Study on Agrobiodiversity
}

\author{
Patricia Lupion Torres' ${ }^{1}$, Neusa Nogueira Fialho', Raquel Pasternak Glitz Kowalski \\ Alexandra Okada ${ }^{2}$ \\ ${ }^{1}$ Pontifical Catholic University of Parana, Curitiba, Brazil \\ ${ }^{2}$ Open University, Milton Keynes, UK \\ Email:glitzkowalski@gmail.com
}

How to cite this paper: Torres, P. L., Fialho, N. N., Kowalski, R. P. G., \& Okada, A. (2016). Responsible Research and Innovation for the Media Facebook: Community Involvement in the Study on Agrobiodiversity. Creative Education, 7, 2141-2150. http://dx.doi.org/10.4236/ce.2016.715212

Received: June 15, 2016

Accepted: September 17, 2016

Published: September 20, 2016

Copyright $\odot 2016$ by authors and Scientific Research Publishing Inc. This work is licensed under the Creative Commons Attribution International License (CC BY 4.0).

http://creativecommons.org/licenses/by/4.0/

\section{(c) (i) Open Access}

\begin{abstract}
This presented research has been developed in Curitiba, Brazil at Pontificia Universidade Catolica do Parana-PUCPR and has organized exhibition by the research group Pedagogical Practice on Teaching and Learning with Educational Technologies-PRAPETEC. This group has partnership with Engage Project that implements practices of Responsible Research and Innovation (RRI), equipping the next generation to participate in scientific issues to change how science is taught. In this context, the question to this investigation was as follows: how to explore the issues related to agricultural biodiversity, specifically to GM products in order to promote RRI? The subject of this study was to promote RRI practice on agricultural biodiversity, emphasis on GM products, in order to disseminate questions directed to this issue, through Facebook social network. This practice has national and international repercussions, with a range of diverse audience participation, involving teachers, students and in general the community from Brazil and other countries. The results show that there is still much to learn about GM products, particularly regards on the identification of these foods, which are genetically modified.
\end{abstract}

\section{Keywords}

RRI, Facebook, Engage Project, GM Food

\section{Introduction}

At the end of the last century, the European Union created the European Group on Ethics in Sciences and New Technologies-EGE, in order to make recommendations 
on the need to consider ethical aspects in technology promotion policies. Recently, the European Commission sought to promote a Responsible Research and Innovation policy, which was linked to the Horizon 2020 program, with the intention of promoting the integration of ethical and social impacts of research on their evaluating processes (Brennan, 2014).

The European Commission introduced the concept of RRI on the last decade to highlight the transparent, interactive and innovative collaboratively process. Thus, according to the European Commission, the RRI is the key action of science and society. This concept is developed within a European Union project called ENGAGE-Equipping the Next Generation for Responsible Research and Innovation and focuses on a methodology based on research.

RRI for the society actors should share their opinions about an innovative product or a new method always using such views on information and ethics. It is worth emphasizing the importance of discussing and evaluating the possible risks and potential benefits inherent in all scientific development process (Sutcliffe, 2011; EC, 2012). To this end, the RRI approach provides the involvement of all, through the discussion of main issues as such: "Why?" "For what purpose and goals?" "Are these desirable?" "What are the motivations?" "Who could benefit and how?" "Who may or not benefit?" (Owen, 2015).

Therefore, scientists and laymen should reflect together about the applications and implications of innovation for society and this process should be inclusive, interactive, anticipatory and transparent, based on social needs, expectations and ethical values to better align the results of innovation (Okada et al., 2016).

In this sense, the RRI is another step towards what was considered already for decades by the European Union as a process of outmost importance, "now with the explicit intention to move from a more abstract or declaratory phase to another more functional and operative" (Boyd, 2014: p. 52). As a result, these referrals has established the need for a differentiated educational process for the next generation in order to ensure scientific literacy and RRI, aiming as public engagement on scientific processes and decisions to innovation (Ratcliffe \& Grace, 2003; Ryan, 2015).

\section{Responsible Research and Innovation: The Inclusion of Citizens in the Digital Age}

The RRI approach implies that social actors work together throughout the process of investigative and innovation in order to align the procedures and their results to the values, needs and expectations of the society (European Commission, 2012).

It is then, an inclusive approach to ensure that social actors can understand the risks and benefits of scientific progress and make responsible decisions (Von Schomberg, 2013). Similarly, the RRI believes that the technology and the progress of science are the basis for a better future. However, innovations must be carefully planned to meet the needs of society in accordance with social values in order to maximize the benefits and reduce any harmful impact (Sutcliffe, 2011). 
One of the European Union projects that promote RRI actions is the ENGAGE. This project aims to spread the teaching and learning through RRI, connecting science and technology with educational materials (Sherborne et al., 2014).

The curriculum developed by ENGAGE involving RRI provides a framework that integrates four areas of knowledge of science and society: technology impact, big science, values thinking and science media. Moreover, this curriculum is based on ten scientific research skills to RRI, in order to provide students with the active engagement in contemporary science. These skills are interrogating sources, using ethics, examine consequences, estimate risks, analysing patterns, criticizing complaints, justify opinions, communicate ideas, prepare questions and draw conclusions (Okada et al., 2015).

One way to develop these skills and promote RRI practices is using social networks. According to Moreira and Januário (2014: p. 74), "social networks are collective and collaborative spaces of communication and exchange of information". "These networks can facilitate the creation and development of practice or learning communities there is an explicit educational intentionality".

Thus, social networks like Facebook, for example, represent an important alternative to learning and may involve cultural, intellectual, social aspects, among many, that can positively influence society.

\section{Facebook: Alternative Network Knowledge Amplification}

Social networks clearly reflect some of the aspects of transformation that permeate the contemporary science. These networks have revolutionized the ways in which people interact with the world. With social networking knowledge is democratized, breaking the barriers of information and consequently of knowledge.

One of the most popular social networks in Brazil is Facebook, a communication channel that allows the virtual contact between people and gradually gained sympathy and preference of many Internet users. Through this network it is very easy to establish contacts, acquire knowledge and generate discussions on various issues due to the centralization of information that the network offers a same space.

Facebook has a variety of tools that satisfy various areas of interest and through this channel any citizen can enter the digital era. With its breadth and diversity, social networks can extend their possibilities of study and research and contribute to the amplifying the knowledge of any citizen. Couto (2014, p. 53), describing about social networks, highlights three verbs: to participate, collaborate and share. These verbs "translate the frequent actions, behaviours of thousands of people who not only create networks and affinities, more continuous channels of solidarity, as a network access means access to each other", whether participating, collaborating or sharing.

This knowledge can be produced and shared interactively and collaboratively. Moreover, this way of communication "enables collaborative learning, dialogue, social negotiation and collective construction of knowledge" (Allegretti et al., 2012: p. 56).

Through the Facebook users can learn from each other, exchange ideas and knowledge. This virtual space, in addition to contribute for a strong interaction between sub- 
jects, enables the sharing of experience and research, allowing citizens to reflect about several issues and the formation of ideas and opinions. However, it is important that the shared investigations are conducted responsibly; it is necessary that before sharing any information, the user has sourced the subject so that the reports are legitimate and thus enable sourced production of knowledge.

\section{Methodology}

In this item, we point out the methodological course of the investigation, first presenting the exhibition: Agrobiodiversity, bringing in sequence the research approach, data collection and data analysis.

The question that gave rise to this text was as follows: how to explore the issues related to biodiversity, specifically to GM products, in order to promote Responsible Research and Innovation? Based on this question, we move on to the explanation of the organization and development exposure.

\section{Exhibition about Agrobiodiversity and Community}

This research was conducted in PUCPR through an exposition entitled Agrobiodiversity, organized by PRAPETEC research group, which is integrated by masters, doctoral, faculty members, and PIBIC fellows. This research group participates on the ENGAGE project, part of science on the European Union and aims to promote Responsible Research and Innovation in order to prepare citizens for make conscious decisions.

As the actions for RRI promotion should be through science with and for society, with public engagement, open access, gender, ethics and scientifically education, PRAPETEC research group promoted an exposition with the aim of promoting a practice of RRI about biodiversity, emphasizing on GM products, in order to disseminate questions directed to this issue, through Facebook social network. This exposition took place in the period 9 - 13 November of 2015, at the first moment, and was extended for another week as a request of the public involved.

Diverse researchers participated in this study, starting with the members of the PRAPETEC group and extending to the community, which eventually involved people from Brazil, the United Kingdom, Portugal, among others.

In order to organize the exposition, the following questions were selected: Do you know which symbol identifies GM foods? Would you eat a GM food? You believe to be possible to eliminate pesticides from food? To use or not GM fruit on vegetable juices? What are the community strategies to increase productivity, food security and economic funds? Would you buy GM cereal? Do you believe that you consuming GM foods without knowing it?

These questions were distributed by the exposition panel along with illustrative images, to instigate people's curiosity towards GM products. The images were made by a participant PRAPETEC research group. Figure 1 shows some of the questions displayed on the panel.

These questions led to the academic community of the university leading them to 
investigate more about the exposition theme. However, to disseminate and involve a larger community around the exposition theme, causing new investigative Facebook page was created, shown in Figure 2.

The creation of this page led many students and teachers as well as others in the community, to visit the exposition and post images and videos containing many reflections on the questions. In addition to visiting the exposition and publish their investigations on the Facebook page, some teachers developed the theme agrobiodiversity on classroom, involving their students in exposed questions. Figure 3 shows some works created by high school students, mediated by one of the PRAPETEC teacher.

A remarkable fact on this exposition was to creation of a group of students of the Digital Design PUCPR course, which that produced a series of illustrated GM that

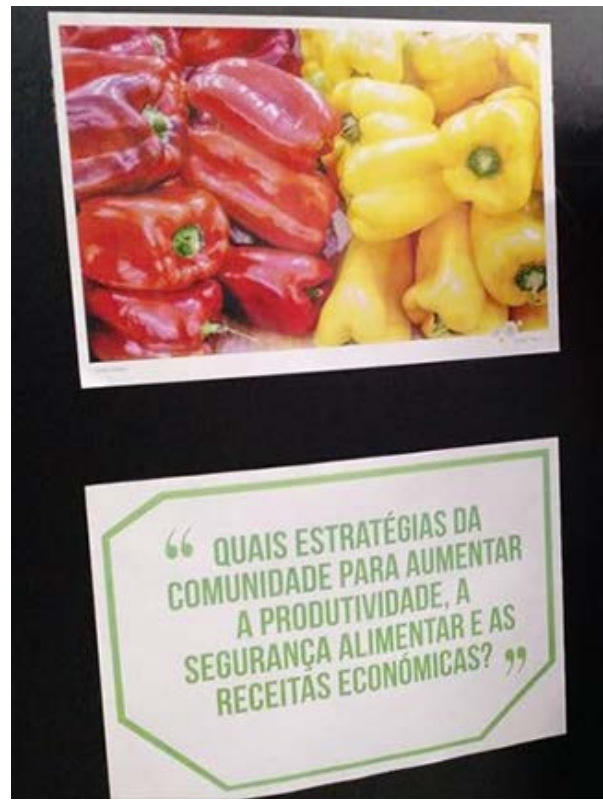

Figure 1. Part of agrobiodiversity exhibition and community.

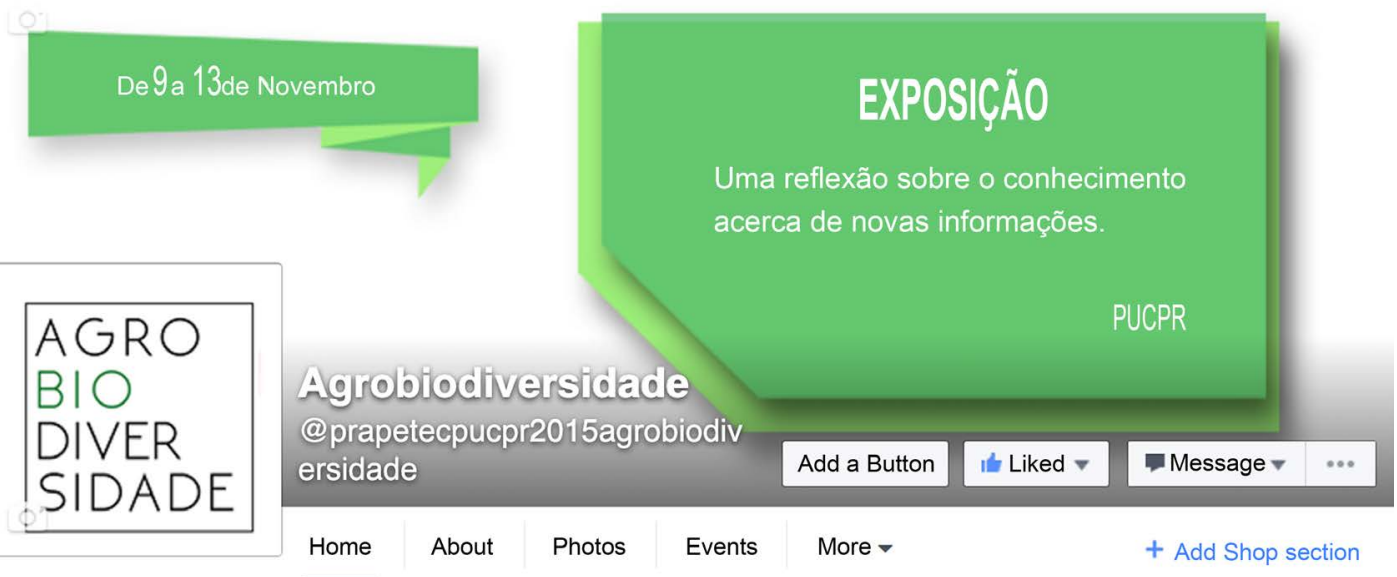

Figure 2. Home and community agrobiodiversity Facebook. 
called much attention of visitors. This produced material was published on Facebook and further enriched the page, shown in Figure 4.

It is emphasized that this exposition was extended for another week at the request of the academicals community and the general public, because the spread of publications posted on Facebook, many participants were interested on visiting.

\section{Methods}

The research here presented is of an exploratory nature, as through the Agrobiodiversity exposition was revolving this theme, especially GM Food products. Exploratory research "is characterized by the development and by clarifying ideas, in order to offer a panoramic view, a first approach to a particular phenomenon that is underexplored" (Gonsalves, 2003: p. 65).

The means of communication, research and knowledge shared by social network Facebook, in whose purpose was to further engage of student community and the general population. With the use of a page created on Facebook was possible to involve a

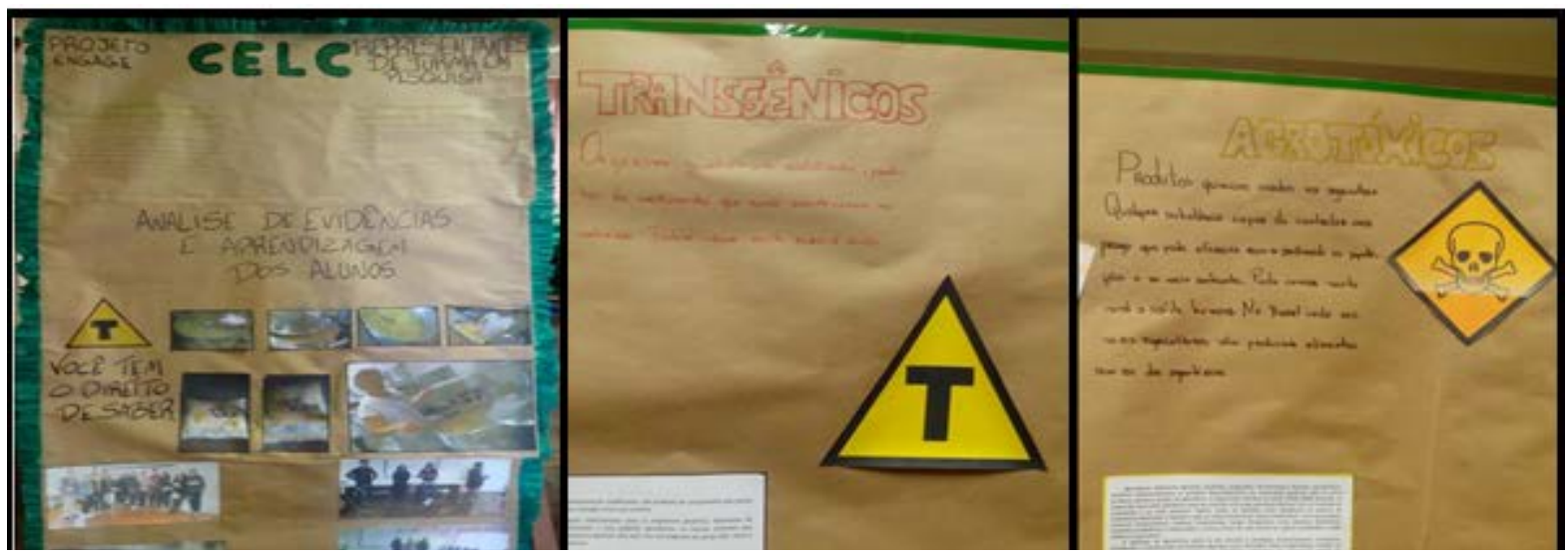

Figure 3. Work on exhibition—high school students in the city of Curitiba/PR.

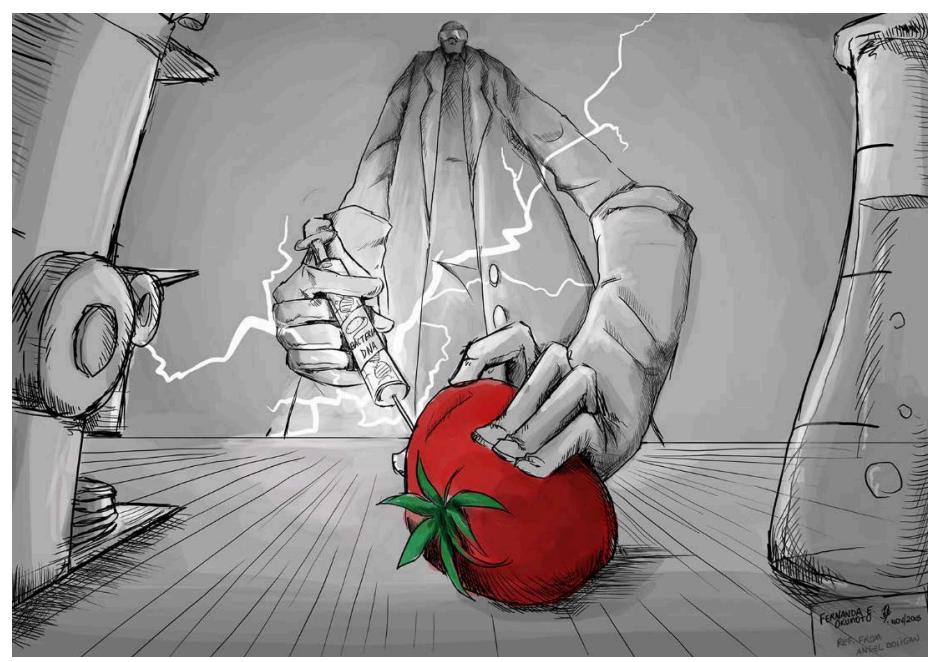

Figure 4. GM food illustrated most likes on Facebook page of the design students-PUCPR. 
wider audience and the questions allowed as a wider exploration of the exposition theme.

As the nature of the research we choose mixed methods of qualitative and quantitative research. Creswell (2013: p. 34) points out "the complexity of our research problems requires answers that are beyond simple numbers in a quantitative sense or words in a qualitative sense". It is understood that "a combination of the two forms of data provides most comprehensive analysis of the problems". So, the data in this research were collected using two instruments. First, through the page created on Facebook to explore the exposition theme, computing statistics, namely, gender and country of the subjects who participated in this thematic exploration; number of people who enjoyed and posted on the page (photos and videos), characteristic of quantitative analysis; and second, the content of postings on videos containing reflections on the theme of the exposition, which is peculiar in qualitative research.

\section{Results and Discussion}

According to the analysis of data generated by Facebook, we found that 340 people liked the page, $75 \%$ women and $25 \%$ men, involving different age groups. However, most of these that liked the page aged 45 - 54 years old, as in Figure 5.

Regarding the country of the research participants, based on the Facebook report, 314 are from Brazil (Curitiba, Colombo, Sao Paulo, Pinhais, Praia Grande, among others); 10 Portugal; 2 Ecuador; 2 Spain; 1 Luxembourg, 1 the United Kingdom and one of the United States of America.

Of these publications in photo format, the most viewed was referred to students of various PUCPR courses, who attended a class on GM food, with vocabularies flagged in LIBRAS (Brazilian Sign Language) and developed text about the theme. This post was from a researcher teacher PRAPETEC group and reached the number of 163 visitors and had 12 post clicks, shown in Figure 6.

As for publications in videos, we found that there were eight posts. Of these, the most Liked was the video that described the exposition in parts, showing the images and questions scheduled for the exposition. This video got 206 views, which are shown in Figure 7.

As for the considerations made by the participants on the GM issue, through videos

The people who like your Page

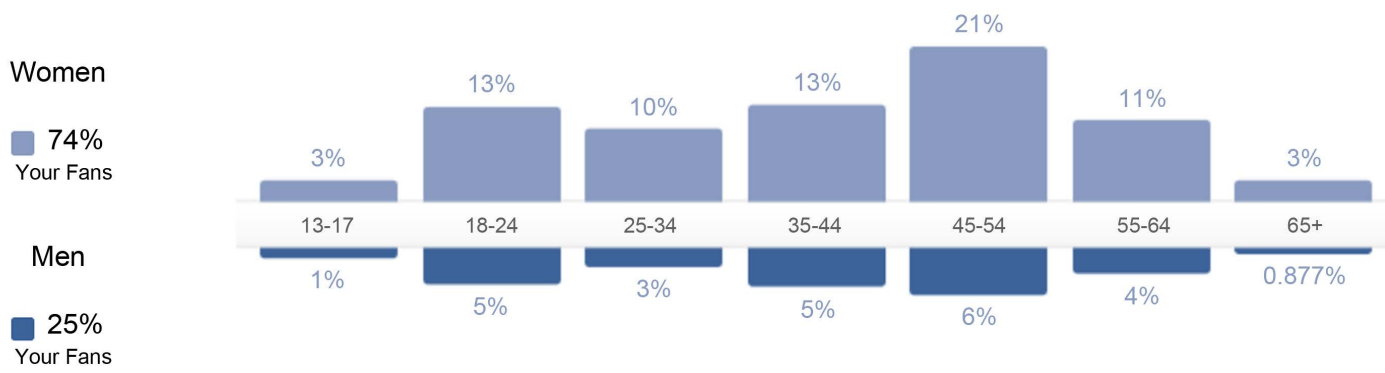

Figure 5. Profile of people who likes the exposure on Facebook page. 
Your 5 Most Recent Posts

\begin{tabular}{|c|c|c|c|c|c|c|c|}
\hline \multirow{3}{*}{$\begin{array}{l}\text { Published } \\
\text { 15/12/2015 } \\
16: 11\end{array}$} & \multirow{2}{*}{\multicolumn{2}{|c|}{ Post }} & \multirow{3}{*}{$\begin{array}{c}\text { Type } \\
8\end{array}$} & \multirow{3}{*}{$\begin{array}{c}\text { Targeting } \\
\text { (3) }\end{array}$} & \multirow{3}{*}{$\begin{array}{l}\text { Reach } \\
128\end{array}$} & Post Clicks & Reactions,comments \& shares \\
\hline & & & & & & Engaement & Promote \\
\hline & $\ldots$ & $\begin{array}{l}\text { Oi Pessoal, Quem participou da e } \\
\text { xposição poderá receber um certi }\end{array}$ & & & & $\begin{array}{l}2 \\
5\end{array}$ & Boost post \\
\hline $\begin{array}{l}03 / 12 / 2015 \\
12: 33\end{array}$ & & $\begin{array}{l}\text { Representantes de turma entrevis } \\
\text { taram acadêmico de Apronomia - }\end{array}$ & De & $\theta$ & 110 & $\begin{array}{l}4 \\
3\end{array}$ & Boost post \\
\hline $\begin{array}{l}01 / 12 / 2015 \\
19: 09\end{array}$ & & $\begin{array}{l}\text { Veja o filme sobre os Transgênico } \\
\text { s está no https://www.youtube.co }\end{array}$ & $S$ & $\theta$ & 119 & $\begin{array}{l}7 \\
17\end{array}$ & Boost post \\
\hline $\begin{array}{l}25 / 11 / 2015 \\
22: 56\end{array}$ & 212 & Muito legal! & 原 & $\theta$ & 118 & $\begin{array}{l}1 \\
1\end{array}$ & Boost post \\
\hline $\begin{array}{l}25 / 11 / 2015 \\
15: 39\end{array}$ & & $\begin{array}{l}\text { Eatudante fala sobre a experiênci } \\
\text { a... }\end{array}$ & 01 & $\theta$ & 163 & $\begin{array}{l}12 \\
4\end{array}$ & Boost post \\
\hline
\end{tabular}

Figure 6. Most viewed post on Facebook page.

Top Videos

Most viewed videos on your Page watched for 3 seconds or more,for videos posted between 11 November 2015 and 31

$\rightarrow$ Video Library December 2015.

\begin{tabular}{|c|c|c|c|c|c|c|c|}
\hline Published & Vodeo & Targeting & $\operatorname{Re}$ & & Views & & Avg Completion \\
\hline $\begin{array}{l}12 / 11 / 2015 \\
15: 13\end{array}$ & 19 Video criado por Neusa Fialho & $\theta$ & 760 & $\square$ & 206 & $\square$ & $\begin{array}{l}16 \% \\
0: 26 / 2: 48\end{array}$ \\
\hline $\begin{array}{l}16 / 11 / 2015 \\
14: 36\end{array}$ & $\begin{array}{l}17 \text { Agrobiodiversidade shared Mirta } \\
\text { Pacheco's video. }\end{array}$ & $\theta$ & 360 & $\square$ & 65 & $\square$ & $\begin{array}{l}54 \% \\
0: 14 / 0: 27\end{array}$ \\
\hline $\begin{array}{l}\text { 25/11/2015 } \\
15: 39\end{array}$ & Estudante fala sobre a experiência.. & $\theta$ & 163 & $\square$ & 56 & $\square$ & $\begin{array}{l}34 \% \\
0: 17 / 0: 52\end{array}$ \\
\hline $\begin{array}{l}13 / 11 / 2015 \\
20: 28\end{array}$ & & $\theta$ & 210 & $\square$ & 47 & $\square$ & $\begin{array}{l}97 \% \\
0: 18 / 0: 18\end{array}$ \\
\hline $\begin{array}{l}16 / 11 / 2015 \\
14: 35\end{array}$ & $\begin{array}{l}\text { Agrobiodiversidade shared Marilda } \\
\text { Behrens's video. }\end{array}$ & $\theta$ & 319 & $\square$ & 45 & $\square$ & $\begin{array}{l}57 \% \\
0: 18 / 0: 32\end{array}$ \\
\hline $\begin{array}{l}\text { 03/12/2015 } \\
12: 33\end{array}$ & 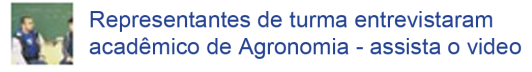 & $\theta$ & 110 & $\square$ & 41 & $\square$ & $\begin{array}{l}14 \% \\
0: 24 / 2: 55\end{array}$ \\
\hline $\begin{array}{l}11 / 11 / 2015 \\
12: 58\end{array}$ & 昰惯 & $\theta$ & 107 & $\square$ & 38 & $\square$ & $\begin{array}{l}99 \% \\
0: 17 / 0: 17\end{array}$ \\
\hline $\begin{array}{l}16 / 11 / 2015 \\
14: 34\end{array}$ & $\begin{array}{l}\text { Agrobiodiversidade shared Deise Choti's } \\
\text { video. }\end{array}$ & $\theta$ & 303 & $\square$ & 31 & D & $\begin{array}{l}46 \% \\
0: 23 / 0: 51\end{array}$ \\
\hline
\end{tabular}

Figure 7. Most viewed video on Facebook page.

defined by characterizing them in: participant one (P1), participant two (P2), participant three (P3) and so on. In addition, they were included only the videos that brought reflections on the exposition theme. 
Thus, the first participant who posted video was in charge of taking the pictures for the exposition. The testimony that participant was interesting, because he said:

It was a different experience. I think almost everything is modify but the problem is that no identification as to whether or not GM food. My work was difficult, because I had to do more research about the subject (P1).

Two videos were posted with answers to the question that asked if the person would eat or not a GM food without knowing it, the answers revealed a lack of knowledge on the subject, because the participants responded as follows:

I would not want to eat GM food, but would not know how to identify than, because some packages do not bring identification, in doubt we would eat than (P10).

I would eat a GM food, because I would not know how to identify it (P2).

The question about community strategies to increase productivity, food security and economic revenue was answered by two participants. Their responses showed awareness of the need to educate the population on the issues of GM food. His reflections were as follows:

First, I think we need to educate the public to know what GM Food is, because they are packages that do not have the symbol. I think we need to get strategies together (P9).

For me this was a great opportunity because I did not know what the symbol of GM was. It is very important this initiative and the use of virtual resources so that people can have a healthier life (P11).

Another participant chose to answer on video the question asking if it is possible to eliminate pesticides from food. The answer was conscious and at the end of the video, this person left a homemade recipe to help eliminate pesticides from food. Thus, in response she said:

I think that you cannot eliminate $100 \%$ of the pesticides in food, but it is important to reduce to the maximum, washing these foods in abundance and also not use soap not to add more chemicals to food. So the solution is to wash in abundance (P3).

The comments made from the participants abovementioned, it was realized that the most interesting point in this exposition was the fact that people do not have knowledge about the GM food. First, because some do not know to identify the subject and secondly, because some packages do not bring explicit GM symbol (T).

\section{Conclusions}

This research has brought important contributions to the participating public, as provided moments of intense research on agricultural biodiversity, especially regarding issues involving the GM products. To answer the proposed research problem conducting a lot of research responsibly was necessary because the participants should publish on the social network Facebook their thoughts and investigations. So not to post missing information, participants had to actually seek reliable sources to maintain responsible proposal RRI practices.

For the majority of the participants, it was an innovative and learning practice. First, because there was a contribution of many teachers, especially PRAPETEC group, to 
work on classroom exposition of the theme, diversified ways and modern strategies. Secondly, because, through the work done in class and posted on Facebook, students, teachers and the community could make questions and conclusions about the use of GM Food products.

We conclude that this practice, which involved the issue of genetically modified products, may represent a more conscious and collaborative process of teaching and learning, allowing the inclusion of various actors and promoting a link between society and science.

\section{References}

Allegretti, S. M. M. et al. (2012) Learning in Virtual Social Networks: The Potential of Connectivity at Two Scenarios. Magazine Contemporaneity, Education and Technology, 1, 56-60.

Creswell, J., \& Clark, V. (2013) Plano. Search Mixed Methods (2nd ed.). Porto Alegre: Penso.

European Commission (2012). Responsible Research and Innovation: Europe's Ability to Respond to Societal Challenges. Brussels: European Union.

https://ec.europa.eu/research/swafs/pdf/pub_public_engagement/responsible-research-and-in novation-leaflet_en.pdf

Gonsalves, E. P. (2003) Introduction to Scientific Research (3rd ed.). Campinas: Alinea.

Moreira, J. A., \& Januário, S. (2014) Social and Education Networks: Reflections on the Facebook as a Learning space. In C. Porto, \& E. Santos (Orgs.), Facebook and Education: To Publish, Enjoy, Share (p. 65). Campina Grande: EDUEPB.

Okada, A., Young, G., \& Sherborne, T. (2015) Innovative Teaching of Responsible Research and Innovation in Science Education. E-Leaning Papers. Open Education Journal Europe, 44.

Okada, A., Young, G., \& Sherborne, T. (2016). Responsible Research and Innovation in Science Education Report. Milton Keynes: The Open University.

https://www.engagingscience.eu/en/documents/

Owen, R. (2015) Responsible Research and Innovation: Options for Research and Innovation Policy in the US.

https://ec.europa.eu/research/innovation-union/pdf/expert-groups/Responsible_Research_and Innovation.pdf

Ratcliffe, M., \& Grace, M. (2003) Science Education for Citizenship. Milton Keynes: Open University Press.

Ryan, C. (2015) Science Education for Responsible Citizenship. Report to the European Commission. http://ec.europa.eu/research/swafs/pdf/pub_science_education/KI-NA-26-893-EN-N.pdf

Sherborne, T. et al. (2014) ENGAGE: Equipping the Next Generation for Active Engagement in Science. http://cordis.europa.eu/project/rcn/111469_en.html

Sutcliffe, H. (2011) The Report on Responsible Research \& Innovation.

https://ec.europa.eu/research/science-society/document_library/pdf_06/rri-report-hilary-sutcli ffe_en.pdf

von Schomberg, R. (2013) The Vision of Responsible Innovation. In R. Owen, M. Heintz, \& J. Bessant (Eds.), Responsible Innovation (p. 21). London: John Wiley.

https://renevonschomberg.wordpress.com/implementing-responsible-research-and-innovation/ 
Submit or recommend next manuscript to SCIRP and we will provide best service for you:

Accepting pre-submission inquiries through Email, Facebook, LinkedIn, Twitter, etc. A wide selection of journals (inclusive of 9 subjects, more than 200 journals)

Providing 24-hour high-quality service

User-friendly online submission system

Fair and swift peer-review system

Efficient typesetting and proofreading procedure

Display of the result of downloads and visits, as well as the number of cited articles

Maximum dissemination of your research work

Submit your manuscript at: http://papersubmission.scirp.org/

Or contact ce@scirp.org 